\title{
THE SPEeCH IN THE COMPOSITE TeXt: STUdies IN THE MEdiation PROCESS for SOURCES OF RHETORIC IN THE DEIPNOSOPHISTS OF ATHENAEUS OF NAUCRATIS
}

Fee-Alexandra Haase, United International College in Zhuhai of Hong Kong Baptist University and Beijing Normal University, fahaase@uic.edu.hk

Original scientific paper

DOI: 10.31902/fll.32.2020.8 UDC: 821.14'02:808.51

\begin{abstract}
The Deipnosophists is a literary work that presents an insight into ancient rhetoric and speech from various perspectives, while its author, Athenaeus of Naucratis, has a mediating function in the process of communicating this knowledge besides other topics of knowledge about ancient cultures to the readers. Being composed of fictive speeches that join the texts of ancient writings in paraphrases and citations in the conversations of the participants during a banquet, the work reveals in different layers information about rhetoric. Rhetoric is present in the composition of the work itself. In the conversation's speech is present as the essential form of this piece of literature and one component of this composite text. But also, the writings of other authors reflect knowledge about rhetoric as the scholarly discipline for speech. We argue that Athenaeus invents and composes here a memory that arranges topics related to the culture of banquets in speeches. The speeches range from the factuality of historical accounts about rhetoricians to the fictional story of the event and its speeches. The Deipnosophists blends speeches into each other as conversations of the framing narrative of a meeting of Athenaeus who tells the story of the event to a friend and the speeches of the deipnosophists in the actual event of the banquet. The presentation of the texts of the cited and paraphrased books on rhetoric and anecdotal information about rhetoricians and sophists in the description of the banquet rely on the intensive collection of information recorded in the medium book that the author used for the creation of his own work.
\end{abstract}

Keywords: Rhetoric, Second Sophistic, Banquet, Hellenism, Epideictic speech, Greek literature, Imperial Rome 


\section{Introduction:}

\section{Rhetoric of Speeches in the Deipnosophists of Athenaeus}

How is knowledge about rhetoric communicated? With this question applied to the Deipnosophists of Athenaeus, the aim of this article is to analyze the information about rhetoric that Athenaeus provides us in this book that combines a literary form with an encyclopedic knowledge about Greek customs from the classical time to the fictive speakers' actions and sayings that reflect the time of Athenaeus. The field of rhetoric is present in various layers of the text. So Athenaeus has chosen in his unique blend of a framing narrative with a dialogue between Athenaeus and his friend Timocrates who demands an account of this event with the narrative of the event of the banquet and the narratives of the works of authors that are either paraphrased or cited. The framing narrative of a dialogue of two persons who meet and one of them asks for an account of a banquet has been used by Plato in his dialogue Symposium. The main account is the event of the dinner of the deipnosophists. References from books are cited by the participants, as Athenaeus mentions in Book VII (7.5.) as the technique employed by the participants during the banquet for the subject Fishes:

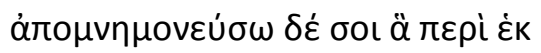

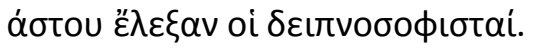

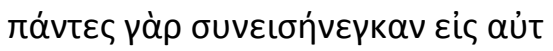

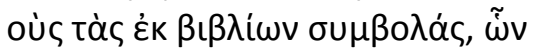

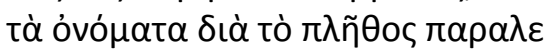
íw.
I will now recapitulate to you what the Deipnosophists said about each: for each of them brought to the discussion of the subject some contribution of quotation from books; though I will not mention the names of all who took part in the conversation, they were so numerous. (Tr. C.D. Yonge)

This part, while being inserted into the narrative of the conversations, is as the narrative layer of the report between Athenaeus and the person he met, Timocrates, in Book $I$ here continued as framing narrative. As for the subject Rhetoric, quotations from speeches of orators, but also other sources providing information about the lives of rhetoricians and their culture exist as another layer. Speech is as unit of spoken uttered words and as rhetorical speech ('入óyos'; 'oratio') present in the text. Athenaeus lets us also in the way his protagonists act and comment on rhetorical issues have a look at the contemporary state of rhetoric in the Hellenic world during the late 
second century. The culture of banquets as social gatherings that existed in all parts of the ancient world known to the Hellenic scholars is realized actively during the dinner of the deipnosophists and all of the topics the deipnosophists discuss in their speeches are thematically bound to the banquet. The banquet in Greece is only one aspect of the work reflecting the historical state of the ancient Greek culture. As the main theme chosen by Atheneus for a cultural history, the author extends this theme even beyond the limits of the Greek culture with information about banquets in other cultures. Atheneaus unfolds its history, while not limiting banquets to literary genres that were exclusively dedicated to banquets. The author connects the banquet to related subjects like food and entertainment in the speeches of the deipnosophists. In Athenaeus' work, several of these writings are quoted that otherwise would have been completely lost. Despite the fictional character of the Deipnosophists Athenaeus reveals in his work biographic details of his own origin from the city of Naucratis in the Western delta of the Nile River during the conversation.

The Deipnosophists is more than a literary work of a fictional event. It contains valuable information about the rhetoric of antiquity until the Second Sophistic from written sources that are exclusively quoted in this work. This concerns the reference to rhetoricians called

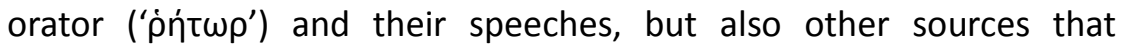
describe the lives of rhetoricians in anecdotal ways giving us an insight of their interaction with professionals from other scholarly or artistic backgrounds. The way that Athenaeus narrates details about the performance and interaction between the participating deipnosophists entails descriptions of how orators act in comparisons of the deipnosophists and the performance of a professional orator. While

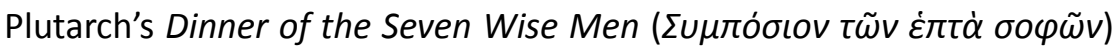
is a fictive conversation of the 'seven wise men' Thales, Bias, Pittacus, Solon, Chilon, Cleobulus, and Anacharsis, Athenaeus chooses fictional contemporaries who gather at the banquet, Here the interaction between the participating deipnosophists has both a discursive structure in the tradition of the genre of the didactic dialogue and narrative and descriptive sequences of the text parts of the speeches delivered by single deipnosophists. The references are the argument for their introductory statement that is linked to the discursive frame of the verbal interaction between the participants. The deipnosophists quote or paraphrase their references after the short introductory statement. The topological structure of the whole work ranges subjectwise across different kinds of topics related to the banquet culture like food and drinks from different areas of the world, cookery, banquets in 
festivals, and entertainment in banquets. In terms of the arguments, it uses the encyclopedic knowledge from books as support for the topics that the deipnosophists employ in their speeches during the banquet. But this encyclopedic knowledge the deipnosophists provide is a real one. The author of the Deipnosophists must have had access to these works. What Athenaeus knew and documented in the Deipnosophists shows us that at the end of the second century CE the works of scholars of the age of Pericles and poetic works since Homeric time were known, preserved, and employed as sources for compositions that use the adaption and implementation of these texts into a new literary form during the Second Sophistic.

At the time Philostratus wrote his Lives of the Sophists the word 'sophist' ('бофıбтn's') was not a general term for an expert but used for the 'orators' ('ṕn'topes'), the professors of rhetoric, in the Roman Imperium who were public figures. In the preface to Book I Philostratus wrote that the old sophistic practice must be considered philosophical

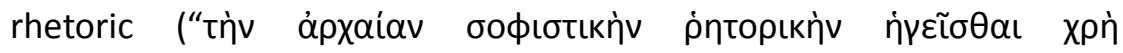
$\phi(\lambda \circ \sigma \circ \phi о$ õ $\alpha v . ")$ due to its dialectical approach. Philostratus, slightly older than Athenaueus, coined the term of the Second Sophistic for the oratory practice of the 'orators' ('ṕńtopes') in the Roman Empire from Emperor Nero onwards. The contextual meaning of the sophist in the time Athenaeus wrote his Deipnosophists was positive. While it can be even seen as an overarching conceptual term for professionals of rhetorical activities in his work, in the dialogues orators are called 'ṕnंtopes', when they appear as the sources of works quoted or as persons in scholarly works.

\section{Research:}

The Deipnosophists of Athenaeus and Rhetoric of the Second Sophistic

While Athenaeus is not named by Philostratus in his Lives of the Sophists, the Second Sophistic is the cultural movement that in many aspects frames the contents, style, and context of the Deipnosophists. So Whitmarsh in The Oxford Handbook of the Second Sophistic asked "What of a text like Athenaeus' Deipnosophists?" (14). The recourse on the classical works of Greek culture and its restructuring to a new kind of composite work that is a bridge between the fictive event of the banquet and the factuality of the ancient writings that are in most of the text present can be seen as a formal feature of writings of the

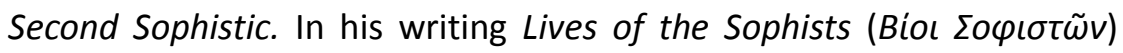
Philostratus unfolded the concept of the Second Sophistic in the form of a biographical account and coined this expression in the Greek 
language. The concept as developed by Philostratus does not apply to Athenaeus who is not recorded in his Lives of the Sophists. Bowie in The Geography of the Second Sophistic. Cultural Variations in Paideia noticed that too little is known about Imperial Naucratis that had four sophists from late second to early third century who are recorded in the work of Philostratus, while this profession was in Alexandria absent and it is not known how these sophists "related to that rather different sort of scholarly figure, Athenaeus" (69).

Johnson and Richter in Periodicity and Scope in The Oxford Handbook of the Second Sophistic argued that for the Greco-Roman world of the second century CE common characteristic of the Second Sophistic of 'nostalgia for an idealized classical past', 'archaism and purity of language', 'sophistic performance and contest and display', 'paideia and erudition', and 'anxieties over self-definition and identity' should be "explored with nuance, sophistication, and sufficient granularity, and with close attention to tensions, ambiguity, and ambivalence" (3). Kemezis in Narrative of Cultural Geography in Philostratus' Lives of the Sophists analyzed the literary structure of Philostratus' Lives of the Sophists and noticed that "the salient geographical feature of Philostratus's story is its emphasis on Athens as the ideal site for sophistic activity". (5) As shown by Eshleman, Philostratus limits the sophists in his work to the three groups of six academic generations from Nicetes through Herodes Atticus to Philostratus, Polemo and his associates, and Isaeus and his students (397).

Recent research has employed the concept of the Second Sophistic as a term for the second half of the first century to the second half of the $3^{\text {rd }}$ century CE applicable to public figures beyond the range of Philostratus' Lives of the Sophists. Anderson stated that there is "no specific branch of 'sophistic rhetoric', though again in practice sophists concentrated on 'epideiktic rhetoric'" (16). As for the Deipnosophists, we have here the fictive event of the banquet and the historical accounts of the cited works in a composite of discourses of the deipnosophists that combine documentation, dialectics, and oratory. Whitmarsh noticed that "although eternally aware of the potentially fictive properties of a discourse, Greeks only rarely acknowledged fiction as a genre: partial exceptions can be found in forms of rhetoric and New Comedy, but it was not until the emergence of the novel in the imperial period that one particular literary form became definitively fictive" (14). Recent research has contributed to the analysis of the stylistically complex form of the Deipnosophists. Anderson (2008: 347) makes a thematic conjecture between Longinus 
who in his On the Sublime discusses in chapter 43 food and refers so to the 'world of the Deipnosophists'. Williamson in Culinary Rhetoric and Rhetorical Cookery. Plato was Right After All noticed that "the deeply rhetorical nature of cooking has been recognized since classic times, particularly in Athenaeus' Deipnosophists, but the full potential richness of a deeper theoretical linkage between discursive scholarship and the culinary arts remains to be explored" (19).

The Deipnosophist is an artifice and the language used in the speeches is by no means ordinary speech. Jacob in The Web of Athenaeus described the various layers of the narration of the Deipnosophists and characterizes in Chapter XIII. Words and Things the language employed by the deipnosophists as a language that "does not correspond to" the "common" Greek (the koinē) spoken in the imperial period, but as one that "has been reconstructed by the work of the grammarians, philologists, and lexicographers of Alexandria, but which also constitutes a relevant object of reflection for the rhetors and prose-writers of the Second Sophistic, in search of stylistic and linguistic norms". Paulus in How to Read Athenaeus' Deipnosophists noticed the interactive dimension of the rhetoric that Athenaeus employs requiring ''readerly' engagement involving inter- and intratext" that "renders Athenaeus' text both meaningful and pleasurable to read". The "understanding this way of reading and its rhetoric enables modern readers to see the Deipnosophists as a literary work rather than merely a repository of knowledge" (403). Olson in Athenaeus' "Fragments" of Non-Fragmentary Prose Authors and their Implications pointed out that "we can generally tell the difference between Athenaeus' quotations (which appear to be more or less reliable) and his paraphrases (which are not)" (423). Romeri acknowledged the interactivity of the text with its praising function stating that 'in Athenaeus' project there is a real work of reappropriation of the quoted texts and that this work corresponds to the author's will to celebrate and to preserve a certain Greek knowledge, thus leading the quoted texts to interact" (17). The uniqueness of the communication style during the banquet in the Deipnosophists has been described by Jacob in Chapter XI. How to Speak at Table? as "the result is a coded dialogue, regulated by a series of rules and constraints, which draws multiple and sophisticated effects of meaning out of a virtuoso game of decontextualization and recontextualization, of effects of form and prosody created by the mixing of dialects, metrical structures, literary genres, levels of discourse, and forms of knowledge." Speech is an integral element and overarching means for the composition of the different elements of the 
text and the representation of knowledge in the Deipnosophists. It is the carrier of the persuasive function of rhetoric. In the following sections, we will analyze how Athenaeus employed speech as the rhetorical means to construct the text of the central event of the Deipnosophists, the banquet, and preserve the knowledge of rhetoric.

\section{What the Deipnosophists Tells Us about Contemporary Rhetoric: \\ Rhetoric, Speech, and Rhetoricians/Orators ('ṕńtopes') at the Banquet in the Deipnosophists}

The Deipnosophists is a work that transforms the knowledge of ancient writings into the vivid dialogues of the conversation in various speeches exchanged between a group of men gathering at a dinner party in Rome. As a reminiscence to the past of Greek culture, the theme banquet is present in various topics of the speeches. While dialogues of dialectic philosophy whose most prominent representative is the Platonic dialogue have an abstract logical and instructive structure, Athenaeus' dialogues are full of detailed information about the lifestyle, habits, and relationships of persons and the speeches of the deipnosophists entail for the most part narratives. Athenaeus builds bridges between the massive use of original quotations in the extant books of Deipnosophists and the proclaimed vivid dialogues they represent in a quite simple way he explains in Book VI: The speakers at the banquet arrived prepared for their speeches with available quotations from books to be used in their performances. The Suda describes in its entry for Athenaeus of Naucratis the author of

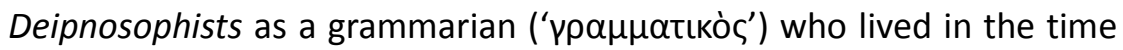
of Emperor Marcus Aurelius and "wrote a book with the title Deipnosophists (' $\Delta \varepsilon \iota \pi v o \sigma o \phi ı \sigma \alpha i$ '), in which he records how many of the ancients had a reputation for munificence in giving banquets"

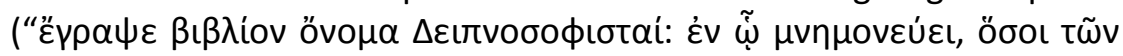

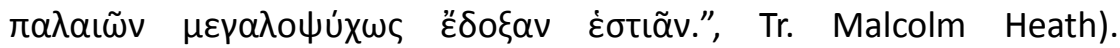
Athenaeus appears in the Deipnosophists as a person we can identify as factual providing us with information about the place he came from, the Greek emporium Naucratis on the Canopic branch of the Nile River. Athenaeus provides not only details about the local food of the city (11.61.) but also lets the participating deipnosophists cite works like the History of the Foundation of Naucratis of Apollonius' of Rhodos or Naucratis (7.19.).

In Book I (1.1.) Athenaeus is described as one of the persons that attends the banquet with the appearance of an orator. His work is 'an

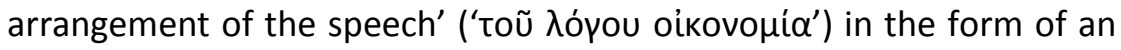




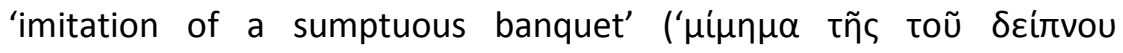

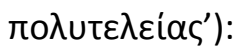

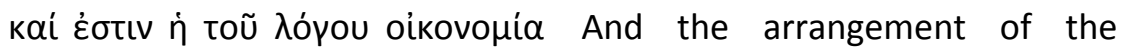
$\mu \dot{\mu} \mu \eta \mu \alpha$ tก̃ऽ toũ $\delta \varepsilon i ́ r v o u$ conversation is an imitation of a

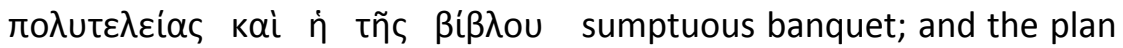

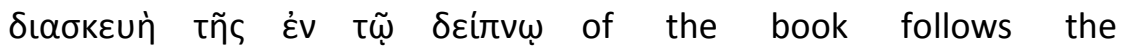

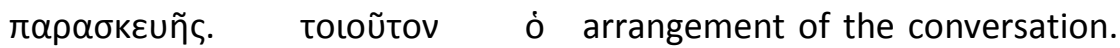

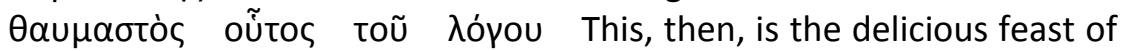

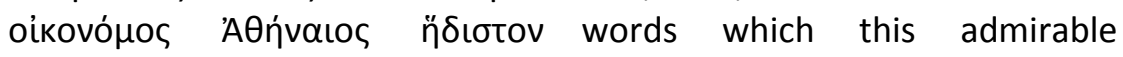

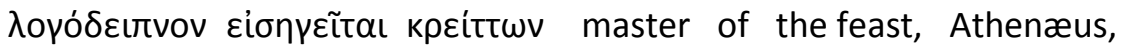
$\tau \varepsilon$ aủtò $\dot{\varepsilon} \alpha u t o u ̃ ~ \gamma ı v o ́ \mu \varepsilon v o \varsigma$, has prepared for us; and gradually

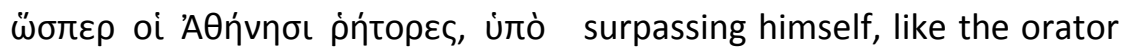

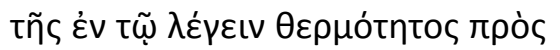

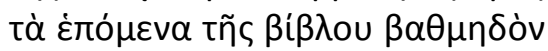

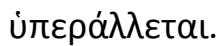

(Ed. G. Kaibel)

at Athens, as he warms with his subject, he bounds on towards the end of the book in noble strides.

(Tr. C.D. Yonge)

In Book I (1.2.), Athenaeus wrote that a group of rhetoricians ('ṕntóp $\omega v^{\prime}$ ) was present at the banquet, but records none of them by name:

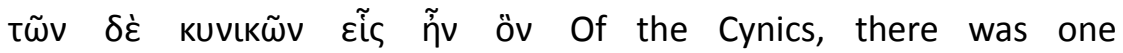

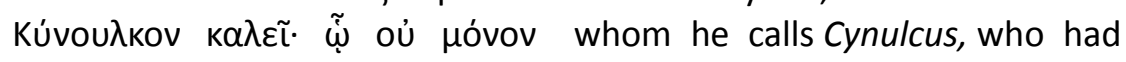

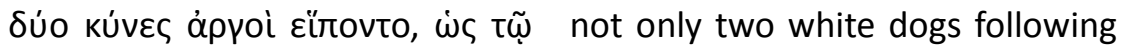
$T \eta \lambda \varepsilon \mu \alpha \dot{\alpha} \chi \omega \dot{\varepsilon} \varepsilon \kappa \lambda \eta \eta \sigma \alpha \dot{\alpha} \zeta o v \tau \iota, \dot{\alpha} \lambda \lambda \dot{\alpha}$ him, as they did Telemachus when

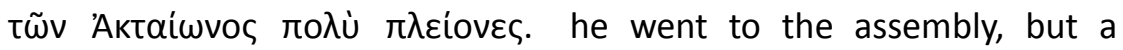

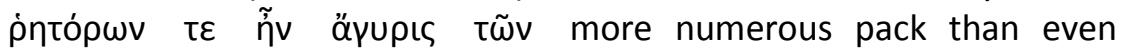

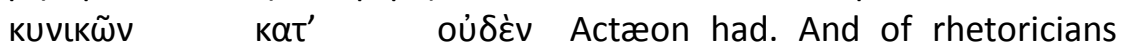

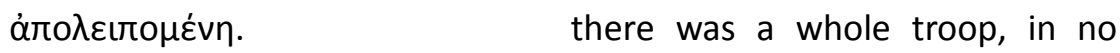
(Ed. G. Kaibel) respect inferior to the Cynics. (Tr. C.D. Yonge)

In Book II (2.20.) Athenaeus writes that he after having delivered

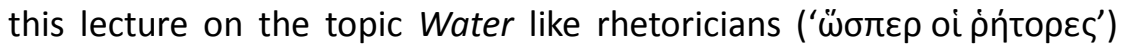
stopped his speech and then started again. The host of the banquet, Laurentius, is described as a speaker in the way of an orator

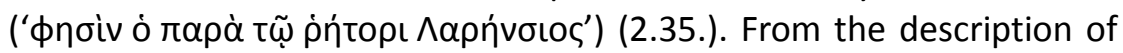
the participating grammarian and text-centered philologist Ulpian we learn in Book III that he was surrounded by sophists who are depicted as the inventors of uncommon meanings for words (3.54.): 


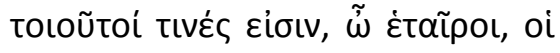

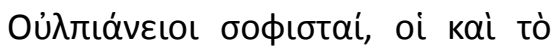

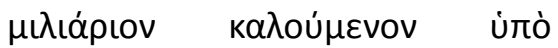

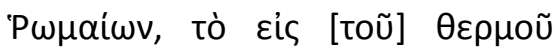

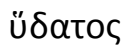

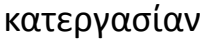

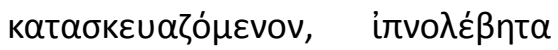

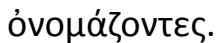

(Ed. G. Kaibel)
Such now, my friends, are Ulpian's companions, the sophists; men who call even the thing which the Romans call miliarium, that is to say, a vessel designed to prepare boiling water in, irvo $\lambda \dot{\beta} \beta \eta$, an oven-kettle. (Tr. C.D.Yonge)

The sophists are called here 'producers of many names' (' $\pi 0 \lambda \lambda \tilde{\omega} v$

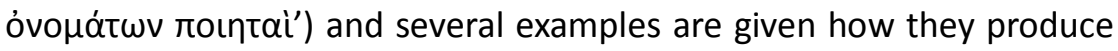
new words or use old words with new meanings based on homophony. In Book VI (6.3.) Athenaeus continues the frame narrative of the beginning of the Deipnosophists that depicts the situation of his meeting with Timocrates who urges him to recall the event of the banquet of the deipnosophists with a reference to the speech of the orator (' $\dot{\eta} \eta \omega \rho ')$ Cothocides saying that he intends to restore the relicts of this feast to Timocrates like Cothocides:

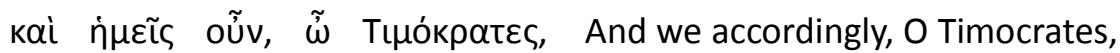

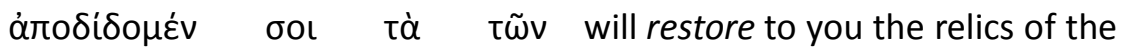

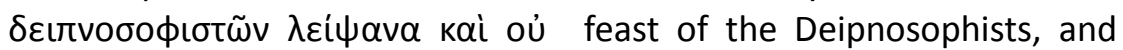

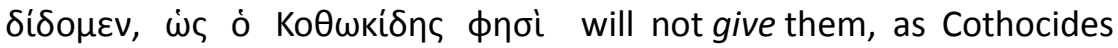

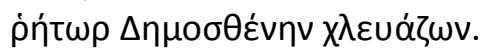
(Ed. G. Kaibel)

the orator said, meaning to ridicule Demosthenes.

(Tr. C.D. Yonge)

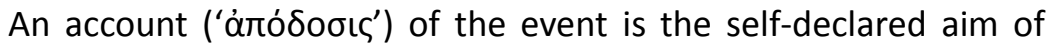
the author. Athenaeus in Book VIII (8.47.) mentions that one of the participating guests at the dinner, Democritus, esteems Aristotle, other

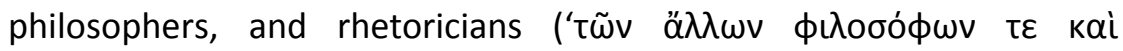
j̀ntó $\left.\rho \omega v^{\prime}\right)$.

The narrative practice that the host and guests who attended a banquet shared a common topic and presented one after the other during the banquet their speeches about this topic is known from Plato. The Symposium of Plato is a meeting with the central topic Eros, to which each of the participating speakers contributed. In Athenaeus' work the event, the banquet, and its topic of the speeches are identical, even though its various aspects are discussed to a degree that lets the banquet appear as a symbol of a universal pleasant and cultured lifestyle. The idea to use the knowledge preserved in a library, books about all kinds of knowledge that contribute to the main topic as material of the narratives of the participating dinner sophists not only 
shows us the creativity of the invention of the author, but also the presence and availability of this knowledge for scholars like Athenaeus in the second century CE. The banquet takes place in Rome, the center of the Roman Empire, while the culture of Hellenism and its past and other cultures serve as the places the works in the discourses refer to. The readers experience the culture of banquets in the narratives of the speeches, while the actions of the event in Rome are only described to the degree that they build a framing structure. With the praise of the banquet itself as an event, the imperial impact of Rome as the center of the contemporary culture, and the esteem for the locations and local cultures in the world known to scholars at that time, a wide range of persuasive intentions make this work comparable to an epideictic speech. The deipnosophists present a vivid memoria of the past and connect this esteemed memory with the present time of the deipnosophists who gather together in the banquet and revive it in their speeches. This blending illusion of a continuity of past cultures and the present culture of Imperial Rome is the persuasive function of the text that is realized by the chosen medium, the speech that revives that past during the event of the banquet.

\section{Banquets as a Theme in Greek Culture and Hellenism}

\section{to the Second Sophistic in the Speeches of the Deipnosophists}

The banquet that Athenaeus here constructed imitates a banquet with representative participants that contribute to the conversation being well-prepared for their particular topic with their citations from classic books in order to demonstrate their expertise. One of the topics is the history of the banquet culture itself. In one case, in Book IV (4.13.), an orator, Xenocles, is mentioned as the host of a banquet in the description of Plutarch about an Attic banquet the parodist Matron

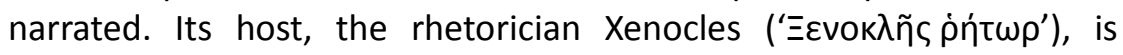
mentioned in the following poetic invocation formula for the Muse:

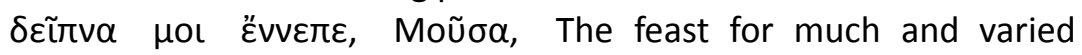

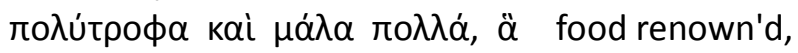

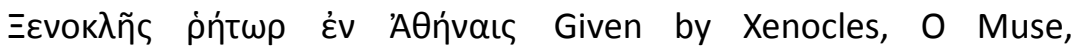
$\delta \varepsilon i ́ \pi v เ \sigma \varepsilon v \dot{\eta} \mu \tilde{\alpha} \varsigma$. resound.

(Ed. G. Kaibel)

(Tr. C.D. Yonge)

The banquet was a literary motive and topographic place for the presentation of discourses among participants in the Greek culture. Athenaeus' work mentions and quotes several works with the title Banquet besides poetic, scholarly and historical works with other titles that entail passages of descriptions of banquets. In Book I the poet 
Archestratus is mentioned as the author of the writing The Art of

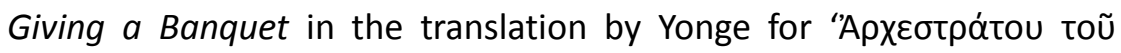

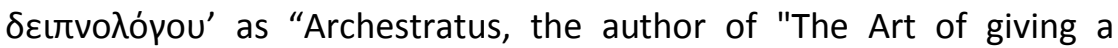
Banquet," says," quoted in the following passage. The compound

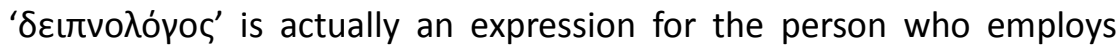

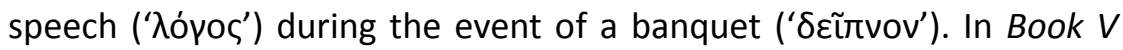
the traditions of banquets are described in various cultures beginning with the poetry of Homer in Greece extending to other parts of the world like Germany, Egypt, Persia, and India with quotations from works of authors that entail the banquet as a topic.

For works exclusively dedicated to a particular kind of feast, the

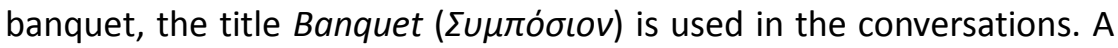
classic writing with the title Banquet well-known to Athenaeus has survived under the title Symposium for the dialogue written by Plato recording a symposium attended by Socrates and other scholars who discuss the common topic of love from various perspectives. Banquet

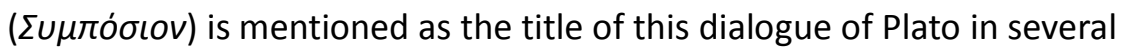
books in the Deipnosophists ((5.5.), (5.7.), (5.18.), (5.57.), (11.108.), (11.114.)). Additionally, Plato's first book of the Laws on Banquets is cited here describing that under the dominion of Lacedaemon, no drinking parties existed even during the time of the Dionysiac festival of Bacchus (5.43.). The title for the work Banquet written by Xenophon

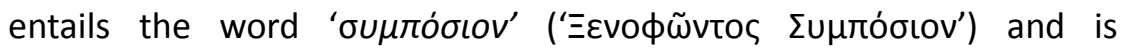
mentioned in several books of the Deipnosophists ((5.13.), (15.34.), (11.111.), (14.3.)). Among the deipnosophists, it was known that the rivaling philosophers Plato and Xenophon had both written works with

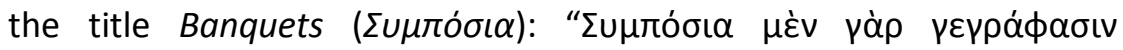

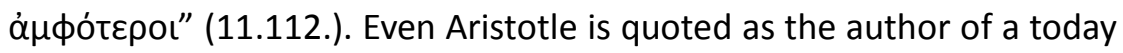

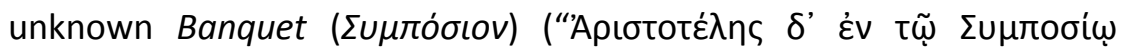
фnoiv") (15.16.). In Book VI (6.2.) Athenaeus tells that laws for banquets were laid down by Xenocrates in the Academy and later Aristotle continued with these guidelines for banquets. Heraclides of Tarentum appears twice as an author of a treatise with the title

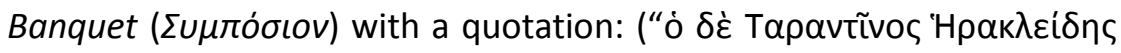

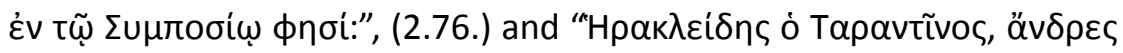

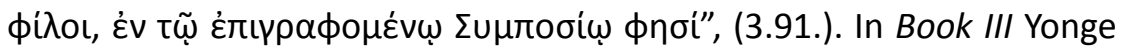
translates a title of a quoted book of Lynceus 'an account of the Banquet of Ptolemy', while the original text does not use a capital letter

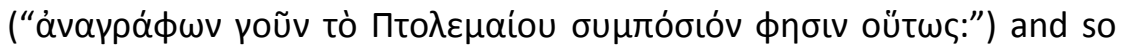
the original text indicates an event rather than a book (3.58.). A work

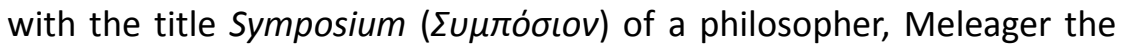

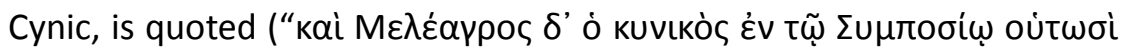




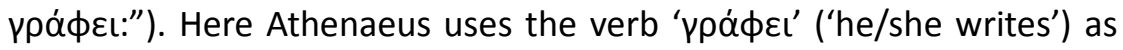
an alternative to the verb 'фnoi' ('he/she says') for the introduction of the author's work (11.107.).

In Book XIII Athenaeus wrote that the Stoic philosopher of the third century BCE Persaeus the Cittiaean made an account with the title

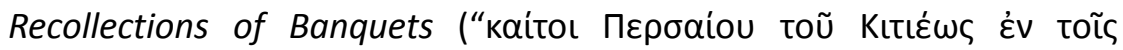

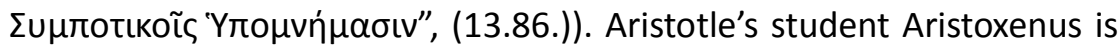

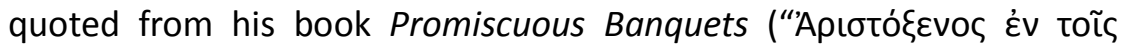

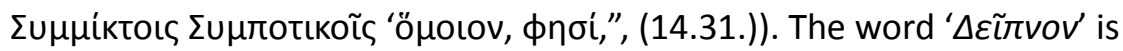
used for the title of literary works in the Deipnosophists. Philoxenus'

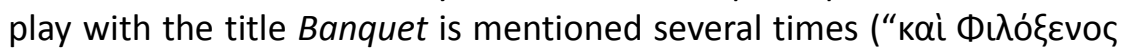

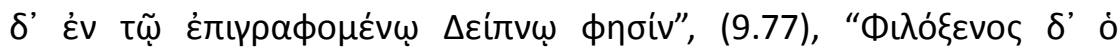

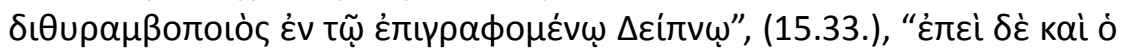

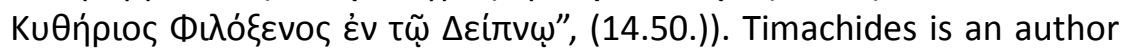
who is quoted three times from his several books comprising work Banquet ("

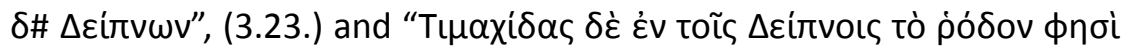

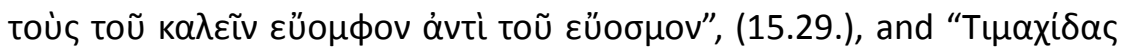

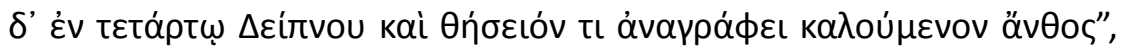
(15.32.).

\section{Speech and Rhetoric and Rhetoricians / Orators ('ṕńtopєs') in the Cited and Re-Narrated Books of the Deipnosophists}

\section{Greek Rhetoric and Roman Oratory as Speech Topic:} The Social Status of Rhetoricians / Orators in the Deipnosophists

Reading the Deipnosophists as a media composite of different texts from a time before the concept multimedia in it contemporary definition was used means to acknowledge the media that existed at the time Athenaeus flourished for communication: they were spoken and written speeches that were in the rhetorical theory highly differentiated, produced as artifices of different genres, and reflected in scholarly writings of different fields of expertise. Recorded in Greek books once written in the past and well-preserved in late antiquity of the Imperium Romanum, these texts enabled Athenaeus to produce his literary composite. Despite its fictionality, we can show that the conversations of the banquet as Athenaeus' unique invention refer to contemporary rhetoric. The factual scholarly work and literary artifacts that appear in the conversations refer to the past of the oratory culture as a means of documentation. The citations of the books often are introduced with the word ' $\phi \eta \sigma i$ ' ('he/she says') marking the beginning of the paraphrase or original text quotation as a speech. So in the 
conversational speeches of the banquet, the texts of the written works quoted are introduced as a speech by their respective author. Both kinds of speeches, the spoken and written, that are delivered during the banquet, are the implementations of the framing speech that Athenaeus delivers to his friend as the recollection of this event in the frame narrative.

As a practice of rhetoric in the mythos, in Book I (1.28.) during the discussion about banquets in Homer's poetry Athenaeus wrote that the Trojans honored at the end of their banquets Mercury to whom the 'tongue' (' $\gamma \lambda \tilde{\omega} \sigma \sigma \alpha$ ') as instrument of 'interpretation'

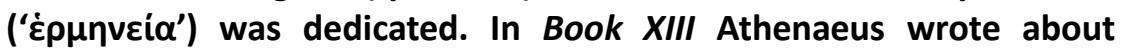
rhetoric in the time of Aristotle. Athenaeus mentions here that Philo wrote a 'speech' (' $\lambda$ ópoc') against Sophocles who was defended by the cousin of Demosthenes Demochares caused by Sophocles' release of a decree that banned philosophers from Attica:

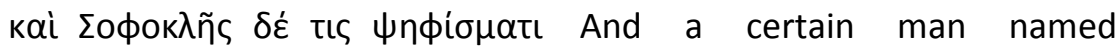

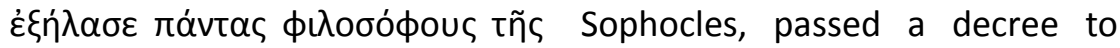

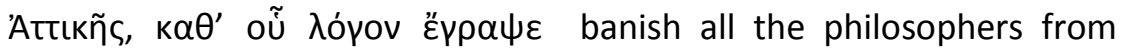

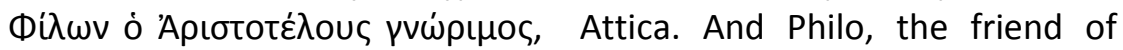

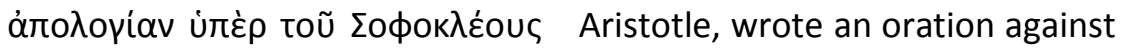
$\Delta$ пноха́рочৎ твпопко́тоৎ той him; and Demochares, on the

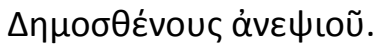

(Ed. G. Kaibel) other hand, who was the cousin of Demosthenes, composed a defence for Sophocles.

(Tr. C.D. Yonge)

It is told in Book XIII that in the Roman Empire sophists were either banned from Rome as persons who corrupted the youth, but nevertheless, the Romans are praised as 'the best in every respect'

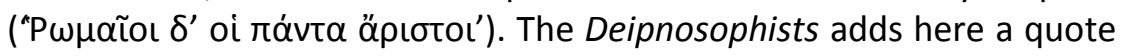
from the poet Anaxippus who mentions that for him "philosophers are

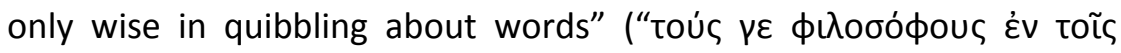

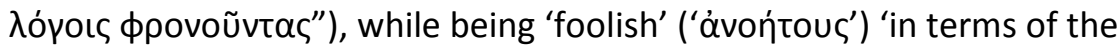

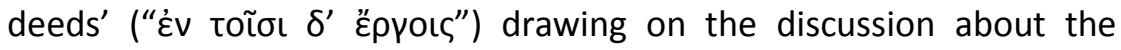
relation between words and things:

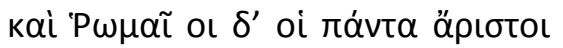

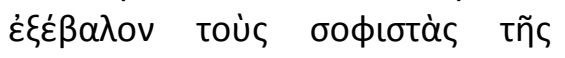

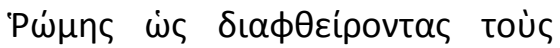

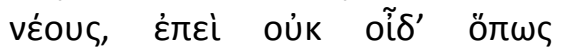

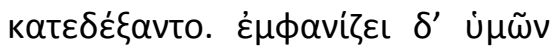

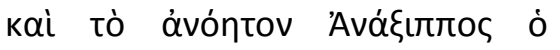

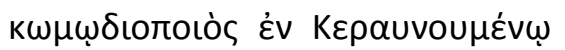

And the Romans, who are in every respect the best of men, banished all the sophists from Rome, on the ground of their corrupting the youth of the city, though, at a subsequent time, somehow or other, they admitted 


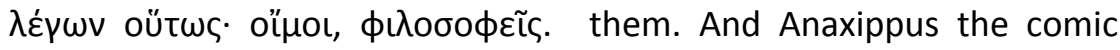

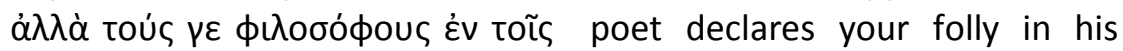

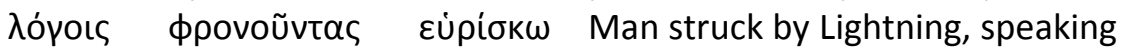

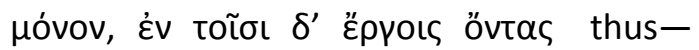
ávońtous ò

Alas, you're a philosopher; but I (Ed. G. Kaibel)

Do think philosophers are only wise

In quibbling about words; in deeds they are, As far as I can see, completely foolish.

(Tr. C.D. Yonge)

The practice of banning philosophers and rhetoricians was common in many cities across Greece during the time of Socrates with reference to Chamaeleon's book on Simonides (13.92.). This contrasting comparison of ancient Greek and Roman politics dealing with philosophy and sophistry and rhetoricians who supported or acted against them describes rhetoricians as public figures involved in political affairs.

\section{Classic Rhetoricians / Orators ('p̉ńtopes') of the Periclean Age as Speech Topic in the Deipnosophists}

\section{The Platonic Circle I: Gorgias}

Gorgias is a well-known person in the Deipnosophists with the profession of an orator ('ṕn $\tau \omega \rho^{\prime}$ '). So in Book $V$ Athenaeus writes that Antisthenes' dialogue Archelaus was written against Gorgias the orator

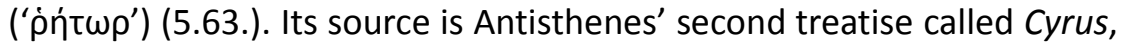
in which the dialogue Archelaus is mentioned. The dialogue Gorgias of

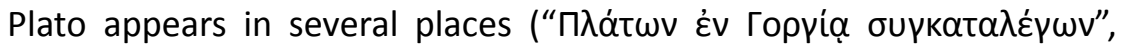
((3.78.), (11.115.), (11.118.)). Athenaeus in Book V (5.58.) quotes from the dialogue Gorgias to show how carefully Plato composed his dialogues. An anecdote tells that Gorgias himself ("ò Гopүías aủtòs") said to his friends that Plato knew how to write iambics well after he read the dialogue about him (11.113.). Other anecdotal details about the life of Gorgias come from Clearchus who wrote in his Lives that Gorgias for more than eighty years used his full intellectual capacities and from Demetrius of Byzantium who recorded that Gorgias lived over hundred years because, as Gorgias stated, he never pleased anyone except himself. (12.71.). The expression 'I spoke in Gorgias-like

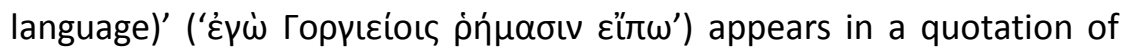


the Banquet of Xenophon (11.111.). Gorgias appears to be the namegiving person of a book with the title Gorgias written by Hermippus (11.113.). In Book XIII Athenaeus recorded that Gorgias wrote a treatise

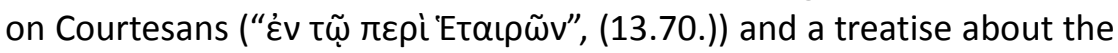

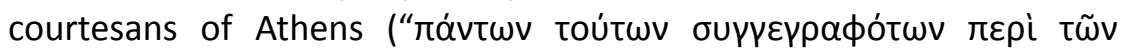

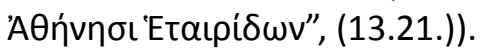

The Platonic Circle II: Aspasia in a Dialogue with Plato as Quoted by Herodicus the Cratetian in the Deipnosophists

In Book $V$ of the Deipnosophists, Athenaueus cites and re-narrates a dialogue between Aspasia and Plato (5.61.). The source for it is Herodicus the Cratetian. Aspasia is not called an orator, but a 'wise

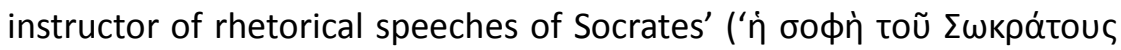

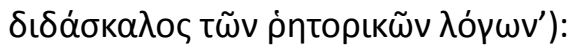

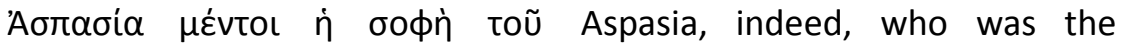

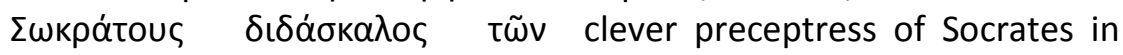

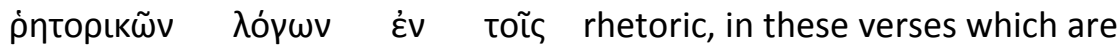

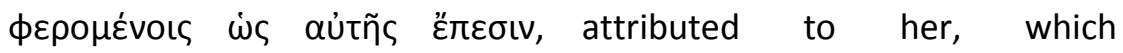

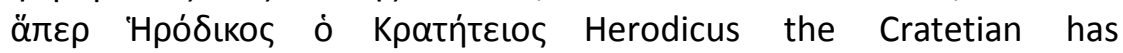

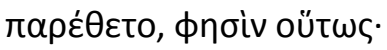

(Ed. G. Kaibel) quoted, speaks thus(Tr. C.D. Yonge)

In the following dialogue, Aspasia advises Socrates to charm Alcibiades

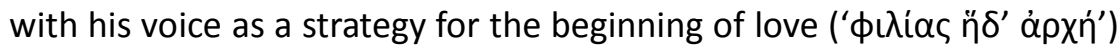
in order to win the love of Alcibiades. The following part is a combination of a dialogue between Socrates and Aspasia and a narration of events. Aspasia is called 'instructor in love affairs'

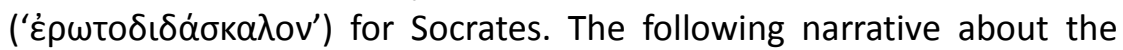
unsuccessful approaches of Socrates towards Alcibiades refers to the Platonic dialogue Protagoras. Book $V$ (5.62.) mentions among the writings of the philosopher Aeschines a work with the title Aspasia. Details about the life of Aspasia are recorded in various sources. So Socrates is supposed to have spent time with Aspasia's flute-playing woman as told by Xenophon in Book II of his Memorabilia. (5.63.). In Book XIII (13.71) it is mentioned that Socrates went to the house of Aspasia:

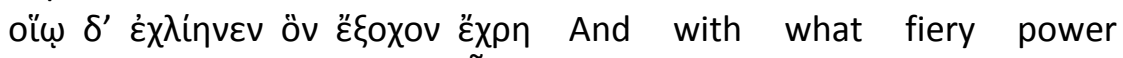

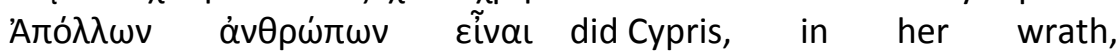

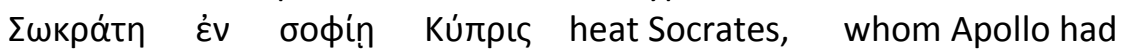

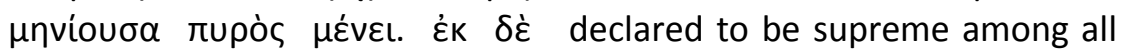

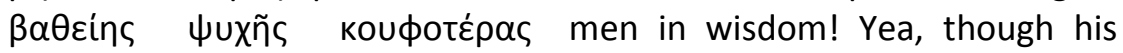

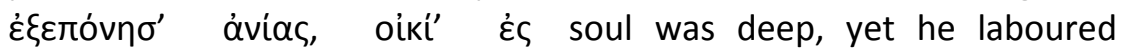




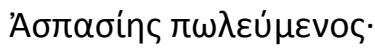

(Ed. G. Kaibel) with lighter pains when he visited the house of Aspasia;

(Tr. C.D. Yonge)

In Book V (5.63.) Athenaeus recorded that the work Aspasia of Antisthenes attacks the sons of Pericles Xanthippus and Paralus. In Book XII about the life of Aspasia Athenaeus writes that Pericles lived

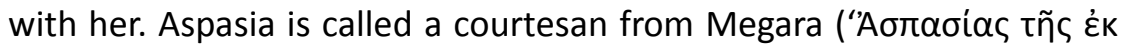

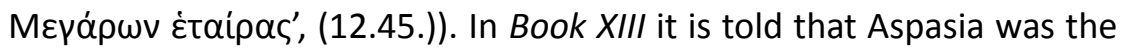

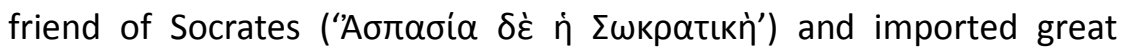
numbers of beautiful women so that Greece was filled with her courtesans with a reference to the Acharnenses of Aristophanes. Aristophanes is here the source for the account that the Peleponnesian war was initiated by Pericles' love for Aspasia (13.25.). In Book XIII (13.56.) the narrator says that according to the account of Clearchus Amatory Matters Pericles caused a state crisis in Greece due to his relation with Aspasia. In Book XIII (13.37.) Athenaeus writes that the name of a courtesan belonging to Cyrus the Younger was changed from Milto to Aspasia.

Rhetoricians / Orators ('ṕńtopєs') from the Alexandrian Canon of Ten Greek Orators as Speech Topic in the Deipnosophists

Athenaeus' Deipnosophists does not refer to the Attic orators of the Alexandrian Canon of Ten Greek Orators in a referential or systematic way, but the names of seven of these orators appear in the conversations. The contemporary philosopher of Plato Isocrates, a student of Gorgias, is called 'orator' ('ṕńt $\left.\omega \rho^{\prime}\right)$ ((3.94.), (13.21.)). In Book $X I I I$ (13.62.) Athenaeus writes that Isocrates is the 'most modest of all

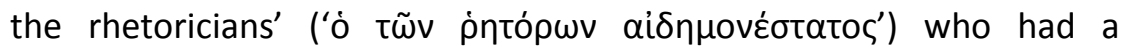
mistress named Metanira with a reference to the Letters of Lysias, while Demosthenes in one of his speeches says that this mistress belongs to Lysias.

The most famous orator of the classic Greek past praised in writings of late antiquity is Demosthenes. In the Deipnosphists many of his speeches are cited. The attribute 'orator' ('ṕn't $\left.\omega \rho^{\prime}\right)$ is given to Demosthenes in several places ((2.22.), (3.57.), (6.62.), (8.31.), (13.31.), (13.54.), (13.63.), (14.3.), (14.53.)). Cothocides is called 'orator' ('ṕńt $\omega \rho^{\prime}$ ) in a quote ridiculing Demosthenes (6.3.). Demosthenes' contemporary rival Hypereides appears also in several places of the Deipnosophists with the profession 'orator' ('ṕn ((3.90.), (6.92.), (8.27.), (12.77.), (13.58.), (14.6.)). Lysias has the attribute 'orator' ('’́ńt $\left.\omega \rho^{\prime}\right)$ throughout the conversations ((12.48.), 
(12.76.), (13.34.), (13.93.), (13.94.)). An anecdote is told about Lysias who was desperately in love with Lagis the courtesan, whose panegyric

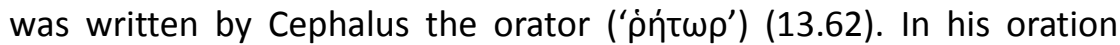
against Philonides Lysias says that Nais was the mistress of Philonides (13.62.). In Book $V$ a speech of Lysias is quoted (5.45.) with the remark that philosophers often are more inclined to evil speaking than comic writers with examples from writings of Aeschines, the pupil of Socrates, and his negative disposition displayed when laughing at Lysias the

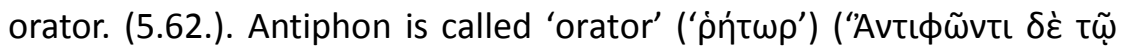

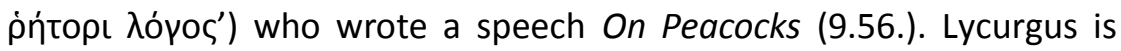

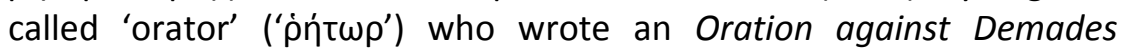

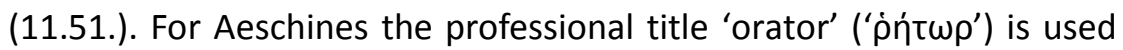
three times in the Deipnosophists (6.41.), (8.22.), (13.30.). According to Demosthenes' oration about the False Embassy, Epicrates who was nicknamed Cyrebion was the son-in-law of Aeschines (6.41.) Aeschines' speech against Timarchus is mentioned (13.30.). Since the orators Isocrates, Demosthenes, Hypereides, Lysias, Lycurgus, Antiphon, and Aeschines are mentioned in the Deipnosophists, while the names of Andocides, Dinarchus, and Isaeus lack, we can assume that Athenaeus did not take into account the Alexandrian Canon of Ten Greek Orators who were selected by Aristophanes of Byzantium and Plutarch in his Lives of the Ten Orators.

\section{Rhetoricians / Orators ('ṕńtopes') of the Forth Century and Third Century BCE as Speech Topic in the Deipnosophists}

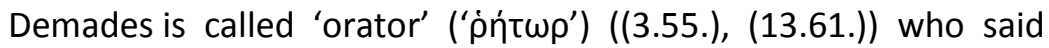
that Aegina was the "eyesore of the Peiræus," and that Samos was "a fragment broken off from the city" (3.55.). Axionicus' work Lover of

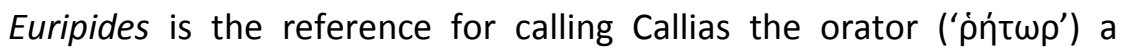
gambler (8.27.). For the fatness of the orator ('ṕn' $\omega \omega^{\prime}$ ') Python of Byzantium his fellow-citizen Leon is used as the reference (12.74.).

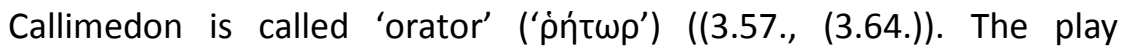
Ponticus of Alexis mentions the orator ('ṕńt $\left.\omega \rho^{\prime}\right)$ Callimedon (3.57.). Athenaeus in Book VIII (8.28.) employs the word 'rhetoricians' ('ṕntó $\rho \omega v$ ') in a quote from the source Physician of Theophilus in a

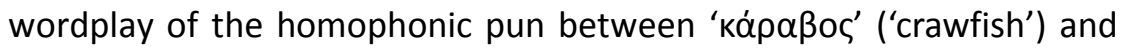
Callimedon's nickname Carabus:

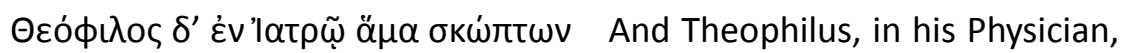

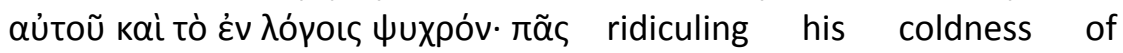

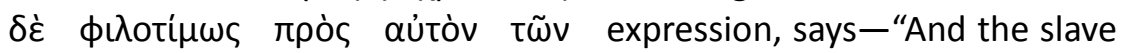

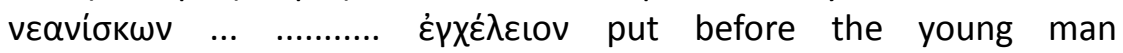

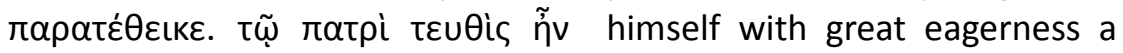




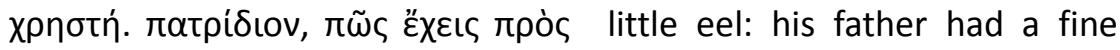

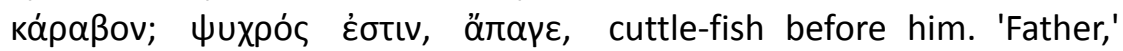

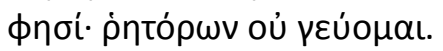

(Ed. G. Kaibel)

says he, ' what do you think of your crawfish ' 'It is cold,' says he; 'take it away, - I don't want to eat any orators."'

(Tr. C.D. Yonge)

Who qualified for Atheneaus to be called an 'orator' ('ṕnt $\left.\omega \rho \rho^{\prime}\right)$ ? The 'brazen poet and orator' ('ṕńt $\omega \rho^{\prime}$ ') Dionysius Chalcus wrote a speech advising the Athenians to adopt a brazen coinage that Callimachus notices in his list of Oratorical Performances (15.9.). Caucalus is an 'orator' ('ṕnंt $\left.\omega \rho^{\prime}\right)$ who has written a panegyric on Hercules (10.2.). Philinus as an 'orator' ('ṕńt $\omega \rho^{\prime}$ ') wrote a debate on the

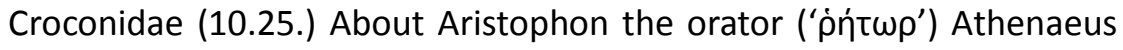
writes that he proposed in the archonship of Euclides a law that everyone who was not born of a woman who was a citizen should be classified as a bastard (13.38.). Nicarete the courtesan was the mistress of Stephanus the orator ('ṕnंt $\left.\omega \rho^{\prime}\right)$ (13.65.). Stratocles is called an 'orator' ('ṕn $\tau \omega \rho$ ') who kept as his mistress a courtesan whose name was Leme in Gorgias' treatise on Courtesans (13.70.) The nephew of Demosthenes Demochares has the professional title

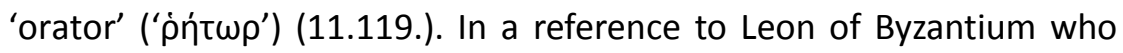
was a student of Aristotle a Python of Byzantium is called 'orator' ('ṕnt $\omega \rho^{\prime}$ ') (12.74.). Baton of Sinope who wrote a treatise on Thessaly and Haemonica (14.45.) is called twice 'orator' ('ṕńt $\left.\omega \rho^{\prime}\right)$ ((14.34.) and (14.45.)). For Cepahlus the title 'orator' ('ṕńt $\omega \rho^{\prime}$ ') is used (13.62.) when mentioning that he wrote a panegyric for the courtesan of Lysias Lagis. The only rhetorician of the Augustan Age who is called 'orator' ('ṕnt $\left.\omega \rho^{\prime}\right)$ is Caecilius ((6.104.), (11.15.)). As for rhetoricians of the second century $\mathrm{CE}$, Herodes Atticus carries the

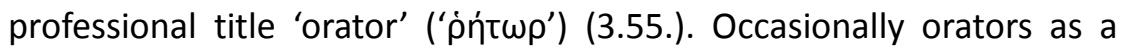
group of professionals are cited by Athenaeus in works of Greek poetry. So in Book X (10.73.) a speech from Antiphanes' play Sappho is cited

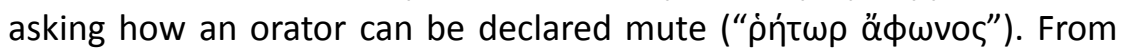
the Knights of Aristophanes a passage is quoted in Book III (3.47.) that mentions orators ('ṕńtopعc'). In Book XIII (13.60.) the narrator says that Herodicus in Book VI of his Essay on People mentioned by the Comic Poets wrote that a courtesan according to the orators ('ṕńtopes') was called Sestos. In the Deipnosophists the title 'orator' ('ṕnं $\tau \omega \rho^{\prime}$ ) is used for representatives of this profession from its earliest beginnings like Gorgias to orators of the $2^{\text {nd }}$ century CE in the age of Imperial Rome like 
Herodes Atticus. The continuity of this term to distinguish the 'orator' ('ṕn $\tau \omega \rho^{\prime}$ ') from other professions shows the ongoing knowledge about this profession, its past, and its representatives at a time and place that has a distance to the classical time of Greek rhetoric. Athenaeus' work is a contribution to the understanding of the history and theory of rhetoric as a documentary source of historical texts. It also reflects the contemporary state of written achivements that convey rhetorical elements into writing of complex compositions. These compositions combine narrative layers within speeches. The work employs one rhetorical figure extensively: The fictio personae. It is used for a revival of the deceased authors. In the quoted sources of their writings that are now uttered in the voices of the speeches of the participating deipnosophists the esteem for the authors of the past is expressed with this vividness of the event of the imaginized banquet.

\section{Atheneaus' Deipnosophists as a Composite of a Mediated Culture of the Past}

Danesi defined in the Dictionary of Media and Communications multimodality as the "use of several channels to access the same information" and "the mixing of media forms" (204). The term 'multimedia' is modern and commonly applied for a computer system "that allows the user to manipulate and use different types of media, such as text, sound, video, graphics, and animation." (Danesi 203). Athenaeus' work was technically limited to the medium of the handwritten book as a means and device of communication that allowed information to be systematically arranged, recorded, and communicated. Elements of multimediality are present both in dialogues and quotations from literature as written speech in the Deipnosophists. Structurally the work employs as a unit of a written text a fictional sound of the speeches and writing as quotes from the ancient scriptures that in most cases are not altered in the speeches. Despite the fact that this work contains no images, with its visual appeal to bring evidence by details of the mise-en-scene, the place of the banquet, the work requires the reader to follow the imagination of the event of the banquet. As a narrative about an event in a chronological process of its description it adds elaborated details about the actions, behaviour and the interactions of the speakers, and the course of the dishes and entertainment program. At the same time the reader can consider the quoted text parts as a type of documentation of ancient works or as text parts of the conversation of the deipnosophists in the tradition of the discursive method of the scholarly dialogue that existed in ancient Greece. The reader can 
interactively chose the mode of the usage of the selected text parts of the work or the whole text. The reader can interpret and use it as a fantastic fictional narrative, a fictive account of events during the time of the Roman Empire that provides clues about the politics and culture of Rome, a kind of dialogue, or a reference work that accumulates knowledge of the past as means of instruction, or as a means for the motivation to be actively involved in world of banquetery.

Like often employed at the beginning of the Platonic dialogues, it is a not $\mathrm{a}$ in the dialogue involved person who demands to know what happened during this event of the meetings of the deipnosophists. This demand causes as report the following account of what happened. As a communicative action of response, the writer has in order to tell what has happened the function of a mediating person. Deeply rooted in the antique culture, it is a memory that Athenaeus presents here, and not for example an outlook into the future. Its characteristics as a medium that collects, records, and communicates information stem from the abundant variety of books it employs and combines together in the narrative. What is projected here as part of the current Roman culture aims at the presentation of memorable things in the settings of the contemporary time. Personal details, character traits, or life of the participants of the banquet are not of importance. What characterizes them most is their contribution to the knowledge about the subjects of their talk. They are means for the representation of the knowledge preserved in the writings and the event.

As mentioned, multimediality is a modern term of communication as the process of sharing, not a principle of rhetorical speech or the handwritten book. Multimedial features are present in the text of Athenaeus in the symbolic system of writing. In this system visual, acoustic, graphic, and interactive modes are presented for embedding and sharing what the text presents to the reader from various perspectives: The culture of the banquet. Athenaeus places himself right at the beginning of the text as a medium of the report, when the reader is told that he will give an account. Throughout the main text, as collector and medium of the works cited, Athenaeus is the one who conveys and mediates in his account a composite of the past. Even the scene chosen is a reference to the past of banquetery. His role as one of the participant deipnosophists can be understood as a rhetorical means of evidence. The participating deipnosophists are stock characters that bring us portraits of their professions. The perspective of the ancient professions like grammarians, philosophers, and poets is in the writings of the subjects reflected that are discussed in the conversations. The text is a composite of different text elements. It 
employs both as material sources the books of ancient authors and the invented speeches of Athenaeus as components of the books of his work that combine imagination and scholarly knowledge of the author. The the mixing of media forms as a characteristic of multimodality takes here place in the system of writing in the combination of speech present in the dialogues of the deipnosophists, and writing, the books that are implemented as a part of the speeches. That Athenaeus has a mediating and reporting function is a necessary means for the communication of information about the ancient cultures, in our case the knowledge about rhetoric. The framework Athenaeus created here contributes to the history and theory of rhetoric with its genuine and unique approach to let the deipnosophists act in their speeches establishing a discursive network. It also shows that speech has changed at the time of Athenaeus from a canonical order of handbooks to an apparent simple conversational talk with massive quotations that actually presents knowledge about antiquity in its most direct way as an artifice.

\section{Works Cited}

Anderson, Graham. "Rhetoric and the Second Sophistic." A Companion to Roman Rhetoric, edited by William Dominik and Jon Hall. Williston: John Wiley \& Sons, 2008, pp. 339-353.

Anderson, Graham. The Second Sophistic. A Cultural Phenomenon in the Roman Empire. London: Routledge, 1993.

"Athênaios. 'AӨńvaıs".. Tr. Malcolm Heath. Suda Online, edited by David Whitehead. The Stoa Consortium, www.cs.uky.edu/ raphael/sol/sol-cgi-bin/search.cgi. Accessed 5 May 2020.

Athenaeus. The Deipnosophists. Or Banquet of the Learned of Athenaeus, translated by C.D. Yonge. London: Henry G. Bohn, 1854. Perseus Project at Tufts University,

www.perseus.tufts.edu/hopper/text?doc=Perseus\%3Atext\%3A2013.01. 0003\%3Abook\%3D1\%3Achapter\%3D1. Accessed 5 May 2020.

Athenaeus. The Deipnosophists, translated by Charles Burton Gulick. Cambridge, MA: Harvard University Press; London: William Heinemann, 1927. Perseus Project at Tufts University, http://www.perseus.tufts.edu/hopper/text?doc=Perseus\%3Atext\%3A2 008.01.0405\%3Abook\%3D1\%3Achapter\%3D1. Accessed 5 May 2020.

Bowie, Ewen. "The Geography of the Second Sophistic. Cultural Variations." Paideia. The World of the Second Sophistic, edited 
by Barbara E. Borg. Berlin, New York: Walter de Gruyter, 2008, pp.65-85.

Danesi, Marcel. Dictionary of Media and Communications. Armonk, NY and London: M.E. Sharpe, 2009.

Digital Athenaeus. Athenaei Naucratitae Dipnosophistarum Libri 15, edited by G. Kaibel. Project directed by Monica Berti at the Alexander von Humboldt Chair of Digital Humanities at the University of Leipzig. Digital Athenaeus, www.digitalathenaeus.org. Accessed 5 May 2020.

Eshleman, Kendra. "Defining the Circle of Sophists. Philostratus and the Construction of the Second Sophistic." Classical Philology, vol. 103, no. 4, 2008, pp. 395-413.

Jacob, Christian. The Web of Athenaeus, translated by Arietta Papaconstantinou, edited by Scott Fitzgerald Johnson. Washington, DC: Center for Hellenic Studies with Harvard University Press, 2013,

https://chs.harvard.edu/CHS/article/display/5257. Accessed 5 May 2020.

Johnson, William A.; Richter, Daniel S. "Periodicity and Scope". The Oxford Handbook of the Second Sophistic, edited by Daniel S. Richter and William A. Johnson. New York, NY: Oxford University Press, 2017, pp. 3-11.

Kemezis, Adam. "Narrative of Cultural Geography in Philostratus' Lives of the Sophists." Essence et Presence de la Seconde Sophistique. Perceptions of the Second Sophistic and Its Times. Regards sur la Seconde Sophistique et son Époque, edited by Pascale Fleury. Toronto: University of Toronto Press, 2017, pp. 3-22.

Olson, S Douglas. "Athenaeus' "Fragments" of Non-Fragmentary Prose Authors and their Implications." American Journal of Philology, vol. 139, no 3, 2018, pp. 423-450.

Philostratus the Athenian. Vitae Sophistarum. Flavii Philostrati Opera, edited by Carl Ludwig Kayser, vol 2, Leipzig: Teubner, 1871, Perseus Project at Tufts University,

www.perseus.tufts.edu/hopper/text?doc=Perseus\%3atext\%3a2008.01. 0596. Accessed 5 May 2020.

Romeri, Luciana. "Citation et Recontextualisation. Le Cas des Philosophes et des Historiens chez Athénée de Naucratis." Kentron, vol. 30, 2014, pp. 17-32.

Paulas, John. "How To Read Athenaeus' Deipnosophists." American Journal of Philology, vol. 133, no. 3, 2012, pp. 403-439. 
Whitmarsh, Tim. Beyond the Second Sophistic. Adventures in Greek Postclassicism. Berkeley: Univ. of California Press, 2013.

Whitmarsh, Tim. Greece. "Hellenistic and Early Imperial Continuities."

The Oxford Handbook of the Second Sophistic. Ed. Daniel S.

Richter and William A. Johnson. New York, NY: Oxford University Press, 2017, pp. 11-24.

Williamson, Owen M. "Culinary Rhetoric and Rhetorical Cookery. Plato

Was Right After All." Acta lassyensia Comparationis, vol. 11, no.1, 2013, pp. 19-22,

literaturacomparata.ro/Site_Acta/Old/acta11/AIC_11_Williamson.pdf.

Accessed 5 May 2020.

\section{GOVOR U KOMPOZITNOM TEKSTU: UČENJA U PROCESU POSREDOVANJA IZVORA RETORIKE U GOZBI SOFISTA ATENEJA IZ NEUKRATIJE}

Gozba sofista je književno djelo koje pruža uvid u antičku retoriku i govorništvo iz različitih perspektiva, a njegov autor Ateneja iz Neukratije ima posredničku ulogu u procesu komuniciranja čitaocima, uz sva druga, i tog znanja. Sačinjeno od fiktivnih govora koji se u razgovoru učesnika gozbe pridružuju tekstovima $u$ antičkom maniru - u parafrazama i citatima - djelo otkriva različite slojeve informacija o retorici. Retorika je prisutna u komponovanju samog djela. U konverzaciji je prisutna kao esencijalni oblik ovog književnog djela i kao komponenta složenog teksta u cjelini. Ali i u pisanju drugih autora znanje o retorici razumije se kao vještina govora učenih ljudi. Tvrdimo da je Atenej izumio i ovdje prezentovao sjećanje koje sistematizuje teme $u$ vezi sa kulturom gozbi u govorima. Govori sežu od dokumentarnih istorijskih tekstova o retoričarima do fikcionalnih priča o događajima koji takođe inkorporiraju govore. Gozba sofista miješa različite govore, kako razgovore okvirnog narativa o susretu sa Atenejom koji priča o događaju, tako i govore sofista na aktuelnoj manifestaciji gozbe. Prezentacija tekstova o citiranim i parafraziranim knjigama o retorici i anegdotske informacije o retoričarima i sofistima u opisu gozbe temelje se na intenzivnom sakupljanju informacija pohranjenih u medijumu knjige koju je autor koristio za sopstveni rad.

Ključne riječi: retorika, Drugi sofizam, gozba, helenizam, epideički govor, grčka književnosti, carski Rim 